\title{
EXPOSURE OF WORKERS TO OCCUPATIONAL HEAT DURING THE APPLICATION OF PHYTOSANITARY PRODUCTS IN COFFEE CROP
}

\author{
EXPOSIÇÃO DE TRABALHADORES AO CALOR OCUPACIONAL DURANTE A \\ APLICAÇÃO DE PRODUTOS FITOSSANITÁRIOS NA CULTURA DO CAFEEIRO
}

\section{Lucas Deleon RAMIRIO ${ }^{1}$; Paulo Henrique de Siqueira SABINO ${ }^{2}$; Geraldo Gomes de OLIVEIRA JÚNIOR ${ }^{3}$; Adriano Bortolotti da SILVA ${ }^{4}$; Wilson Roberto PEREIRA ${ }^{5}$}

Mestre, Instituto Federal de Educação, Ciência e Tecnologia do Sul de Minas Gerais, Campus Inconfidentes, MG, Brasil. lucas.ramirio@ifsuldeminas.edu.br; 2. Professor Doutor, Universidade José do Rosário Vellano, Campus Alfenas, MG, Brasil; 3. Professor Doutor, Instituto Federal de Educação, Ciência e Tecnologia do Sul de Minas Gerais, Campus Muzambinho, MG, Brasil. 4. Professor Doutor, Universidade José do Rosário Vellano, Campus Alfenas, MG, Brasil. 5. Técnico Administrativo, Doutor, Instituto Federal de Educação, Ciência e Tecnologia do Sul de Minas Gerais, Campus Inconfidentes, MG, Brasil.

\begin{abstract}
During the application of phytosanitary products in coffee trees, workers may be exposed to temperatures that could compromise their health. Exposure to occupational heat can lead to progressive dehydration, cramps, exhaustion and the possibility of thermal shock. Thus, knowing the levels of occupational heat that workers are exposed becomes important. This study aimed to evaluate workers' occupational exposure to heat during the application of phytosanitary products with manual costal pump in the coffee crops. The case study was developed at the IFSULDEMINAS school farm - Campus Inconfidentes in the months of September and October 2017. The occupational heat in the coffee crop was evaluated using the WBGT $_{\text {AVERAGE }}$ method, using TGD 400 thermal stress meter. The WBGT values found were compared to the exposure limits of NR 15 for the purposes of insalubrity classification and with NHO 06 for acclimatized and non-acclimatized workers. The results showed that the WBGT found is below the tolerance limit of NR 15, for the month of September. In October, the tolerance limit was exceeded in the period from 11:00 a.m. to 2:59 p.m., considering a continuous heavy activity and rest in the workplace, and the activity considered unhealthy. Considering the criteria of the NHO 06 it was observed that the limits of occupational exposure were exceeded in the month of October, for acclimatized and non-acclimatized workers. In September the occupational exposure limit of NHO 06 was exceeded only for non-acclimated workers. Therefore, the workers should be submitted to acclimatization during the phytosanitary application activity in the month of October.
\end{abstract}

KEYWORDS: Occupational Heat. WBGT. Acclimatization. Insalubrity.

\section{INTRODUCTION}

The coffee crops to reach adequate levels of productivity receive nutritional sprays and applications of phytosanitary products for the control of insect-pests, diseases and weeds, and the application can be carried out in a manual or mechanized way (BELO et al., 2012; MIRANDA et al., 2016). During the application of phytosanitary products workers may be exposed to conditions of physical effort and environment with high temperature, and the combination of these two factors can lead to thermal stress (VEIGA; ALMEIDA; DUARTE, 2016).

The metabolic rate is the heat generated during the performance of a certain physical activity by the worker, that is, the more intense the activity, the higher the heat produced by the metabolism (SALIBA, 2016). The thermal physiology of the human body functions as a thermoregulator with the function of maintaining the internal temperature around 36 to $37^{\circ} \mathrm{C}$ (VEIGA; ALMEIDA, DUARTE, 2016; KJELLSTROM; LEMKE; VENUGOPAL, 2013).

The thermal overload conditions occur when the body receives more heat than it can dissipate, causing it to rise above $38^{\circ} \mathrm{C}$, and the higher the body temperature, the higher the physiological effects caused by heat (ROSCANI et al., 2017). Workers exposed to occupational heat can suffer health damage, ranging from progressive dehydration, cramps, exhaustion and the possibility of thermal shock (VEIGA; ALMEIDA; DUARTE, 2016).

In Brazil, for the evaluation of occupational exposure to heat, the Wet Bulb Globe Temperature (WBGT) is used, taking into account the variables temperature, wind speed, humidity and radiant heat of the sun according to the Regulatory Norm (NR 15) and Occupational Hygiene Standard (NHO 06) 
Exposure of workers...

(BRASIL, 2017; GIAMPAOLI et al., 2017). The NR 15 classifies as unhealthy activities with occupational exposure to heat, above the exposure limits (BRASIL, 2017; SILVA; TEXEIRA, 2014). The unhealthy working environment interferes directly or indirectly in the quality of life and in the results of the productive process, and may even contribute to increase errors, fatigue, and accident risks. (FIEDLER et al., 2010; YANAGI JUNIOR et al., 2012).

The NHO 06 considers the activities that expose the worker to thermal stress, classifying the workers as acclimatized and non- acclimatized, two conditions that can influence the metabolic activity of the workers. Non-acclimatized workers are those who start activities that involve more critical exposure to occupational heat than those which they were exposed or those who have occasional or periodic exposures in activities in which they are not exposed daily. The acclimatized workers are those who underwent physical activities and successive and gradual expositions to heat, under medical supervision, and reached the conditions similar to those predicted in the work routine. In this way, acclimatization consists of the physiological adaptation to successive and gradual exposures to heat aiming to reduce the physiological overload caused by exposure to heat (GIAMPAOLI et al., 2017).

Knowing the effect of environmental conditions on the metabolic activity of rural workers during the work day is important to reduce the worker's health risks and prevent the activity from becoming unhealthy. In this way, the present study had as objective to evaluate the workers' occupational exposure to heat during the application of phytosanitary products with manual costal pump in the coffee crop.

\section{CONTENTS}

The present case study was carried out in the experimental area of the Federal Institute of Education, Science and Technology of the South of Minas Gerais (IFSULDEMINAS), Campus Inconfidentes - MG, Brazil, located at coordinates $22^{\circ} 18^{\prime} 38.5^{\prime \prime} \mathrm{S}$ and $46^{\circ} 20^{\prime} 09.9^{\prime \prime} \mathrm{W}$ and 869 meters of altitude. The climate of the region is Cwa according to Köppen classification, and the rainfall data indicate that the region has two very characteristic periods, rainy from October to March with precipitations well distributed and another dry, among the months of April and September. The average annual precipitation is around $1.600 \mathrm{~mm}$ and the average temperature is $18^{\circ} \mathrm{C}$.
RAMIRIO, L. D. et al.

The study was carried out in September and October 2017, in a coffee field (Coffea arabica L) cv. 'Catuai Vermelho', 10 years old, average plant height $1.5 \mathrm{~m}$, planted at $2.0 \times 1.0 \mathrm{~m}$ spacing, occupying an area of 2.0 ha.

Two regulations were used to carry out the case study, the NR 15 that is used for the purposes of insalubrity payment and the NHO 06 used to determine the occupational exposure to heat that implies thermal overload, action level and worker acclimatization.

The evaluation of the occupational exposure to heat was conducted simulating a worker performing the application of phytosanitary products using costal pump $(3 \mathrm{~kg})$ with manual operation, with capacity of 20 liters and total weight when being supplied of $23 \mathrm{~kg}$. The metabolism rate used to simulate the worker performing the application of phytosanitary products was 550 $\mathrm{Kcal} / \mathrm{h}$ according to NR 15 or $660 \mathrm{~W}$ determined according to NHO 06, considering continuous fatiguing work with rest on the workplace (BRASIL, 2017; GIAMPAOLI et al., 2017).

Data were collected using a thermal stress meter with a resolution of $0.1^{\circ} \mathrm{C}$ and an accuracy of $\pm 0.5^{\circ} \mathrm{C}$ (MOD: TGD - 400), consisting of wet bulb (tnwb), dry bulb (tdb) and globe (tg). The equipment was coupled on a tripod and installed in a central point of the crop, with the thermometers positioned at $1.70 \mathrm{~m}$ height, considered the median height of the IBGE workers (2009) and greater sun exposure. The evaluations were performed on days with cloud absences avoiding shading at the evaluation point (GIAMPAOLI et al., 2017).

The data records were collected by the equipment's datalogger system, quantifying the WBGT every 60 minutes in the period between 07:00 $\mathrm{h}$ and 16:00 h, performed in a total of 10 days of evaluations in each of the months (September / October 2017).

As determined by Brazil (2017), Giampaoli et al. (2017) and the American Conference of Governmental Industrial Hygienists ACGIH (2018) the evaluation of the WBGT with solar charge was expressed in ${ }^{\circ} \mathrm{C}$, (Equation 1):

WBGT $=0.7$ tnwb +0.2

Eq 1

$\operatorname{tg}+0.1 \mathrm{tdb}$

where:

tnwb = natural wet bulb temperature $\left({ }^{\circ} \mathrm{C}\right)$

$\mathbf{t g}=$ globe temperature $\left({ }^{\circ} \mathrm{C}\right)$

$\mathbf{t d b}=$ dry bulb temperature (Air temperature

$\left.{ }^{\circ} \mathrm{C}\right)$.

The $\mathrm{WBGT}_{\text {average }}$ values obtained were compared to the exposure limit of Table 1 of NR 15 
Exposure of workers...

for purposes of classifying the activity as unhealthy when the temperature is equal to or greater than $25^{\circ} \mathrm{C}$. In order to avoid the insalubrity payment, NR 15 recommends that in the temperatures at the WBGT between 25.1 and $25.9^{\circ} \mathrm{C}$ continuous work is allowed for 45 minutes with rest in the workplace for 15 minutes. The temperatures at the WBGT between 26.0 and $27.9^{\circ} \mathrm{C}, 30$ minutes of continuous work and 30 minutes with rest in the workplace are allowed, with temperatures below $25^{\circ} \mathrm{C}$, continuous work in the working day is allowed (BRAZIL, 2017). Regarding the occupational exposure limit of NHO 06, for acclimatized workers the maximum allowed temperature is $24.7^{\circ} \mathrm{C}$ and non-acclimatized $20.7^{\circ} \mathrm{C}$, for occupational exposure control (GIAMPAOLI et al., 2017).

The WBGT data were submitted to the Shapiro-Wilk test for normality analysis. The data presented normal distribution $(\mathrm{p}>0.05)$ and were submitted to analysis of variance. The interaction among the months and the evaluated schedules was analyzed. The data were submitted to the ScottKnott test at 5\% significance, using software R, version 3.2.4 (R CORE TEAM, 2016).

There was a significant effect on the interaction between the hours and months of the evaluations in the average value of the WBGT index $(\mathrm{gl}=8, \mathrm{~F}=0.275, \mathrm{p}<0.05)$ (Table 1). In September, the maximum registered WBGT for the application of phytosanitary products was of $24.45^{\circ} \mathrm{C}$ at $12: 00$ to
RAMIRIO, L. D. et al.

12:59 p.m. and the lowest registration was of $18.77^{\circ} \mathrm{C}$ at 7:00 to 7:59 a.m. (Table 1). Compared to October, the maximum recorded WBGT for the same activity was of $26.08^{\circ} \mathrm{C}$ at $1: 00$ to $1: 59$ p.m. and the minimum record was of $20.40^{\circ} \mathrm{C}$ at 7:00 to 07:59 a.m. (Table 1). The time interval for October between 11:00 a.m. and 2:59 p.m. exceeded the exposure limit established by NR 15 , which is $25^{\circ} \mathrm{C}$, with the application of phytosanitary products characterized as unhealthy. Vilela et al. (2015) performing work on occupational heat during manual cutting of sugar cane, also observed WBGT levels above exposure limits $\left(25^{\circ} \mathrm{C}\right)$ after 12:00 p.m, remaining this condition until the end of the daily workday that it happened at 03:00 p.m, these results being similar to those found in the present work. Thus, the performance of work accompanied by rest is necessary so that the activity is not considered unhealthy (Table 2) (BRAZIL, 2017).

In the evaluation between the months of working, only in October the average WBGT was not higher compared to September in the hours between 3:00 to 3:59 p.m., for the other hours the average of the WBGT of October was always higher (Table 1). Therefore, non-acclimatized workers who start their activities in October should have great awareness of the heat occupational risks, so there is a reduction in the risks of injuries, health problems and loss of productivity (VARGHESE et al., 2018).

Table 1. Average values of WBGT ( \pm standard error) in coffee crops in the months of September and October.

\begin{tabular}{|c|c|c|}
\hline \multirow{2}{*}{ Schedules } & September & October \\
\hline & WBGT $_{\text {AVERAGE }}{ }^{\circ} \mathrm{C}^{*}$ & WBGT $_{\text {AVERAGE }}{ }^{\circ} \mathbf{C}^{*}$ \\
\hline 7:00 to $7: 59$ a.m. & $18.77 \pm 0.17 \mathrm{~B} \mathrm{e}$ & $20.40 \pm 0.57 \mathrm{~A} \mathrm{e}$ \\
\hline 8:00 to 8:59 a.m. & $20.53 \pm 0.25 \mathrm{~B} \mathrm{~d}$ & $22.29 \pm 0.54 \mathrm{~A} \mathrm{~d}$ \\
\hline 9:00 to 9:59 a.m. & $22.07 \pm 0.34 \mathrm{~B} \mathrm{c}$ & $23.18 \pm 0.60 \mathrm{~A} \mathrm{c}$ \\
\hline 10:00 to $10: 59$ a.m. & $23.13 \pm 0.34 \mathrm{~B} \mathrm{~b}$ & $24.36 \pm 0.57 \mathrm{~A} \mathrm{~b}$ \\
\hline 11:00 to $11: 59$ a.m. & $23.95 \pm 0.36 \mathrm{~B} \mathrm{a}$ & $25.16 \pm 0.58 \mathrm{~A} \mathrm{a}$ \\
\hline 12:00 to $12: 59$ p.m. & $24.45 \pm 0.28 \mathrm{~B} \mathrm{a}$ & $25.96 \pm 0.54 \mathrm{~A} \mathrm{a}$ \\
\hline 1:00 to 1:59 p.m. & $24.31 \pm 0.29 \mathrm{~B} \mathrm{a}$ & $26.08 \pm 0.57 \mathrm{~A} \mathrm{a}$ \\
\hline 2:00 to $2: 59$ p.m. & $24.20 \pm 0.25 \mathrm{~B} \mathrm{a}$ & $25.74 \pm 0.70 \mathrm{~A} \mathrm{a}$ \\
\hline 3:00 to 3:59 p.m. & $23.17 \pm 0.18 \mathrm{~A} \mathrm{~b}$ & $24.22 \pm 0.59 \mathrm{~A} \mathrm{~b}$ \\
\hline CV (\%) & 2.87 & 3.69 \\
\hline
\end{tabular}

Averages followed by the same lowercase letters in the columns and upper case in the lines do not differ by Scott-Knott's test at the 5\% probability level. * Average 10 days of evaluation.

The WBGT of $26.08^{\circ} \mathrm{C}$ found between 1:00 and 1:59 p.m. in October, the working regime would be 30 minutes of rest for every 30 minutes of work according to NR 15 considering as heavy activity (Table 2). Regarding to working hours in the WBGT interval of 25.1 to $25.9^{\circ} \mathrm{C}$ the working regime would be 45 minutes of work and 15 minutes of rest (Table 2). Since the occupational exposure limit represents the conditions under which it believes that the majority of workers may be repeatedly exposed throughout their working life without suffering effects on their health (GIAMPAOLI et al., 2017; ACGIH, 2018).

Thus, it is important to highlight that the thermal overload that the worker can be exposed is related to the combination of metabolic heat, 
Exposure of workers...

environmental factors (WBGT ${ }^{\circ} \mathrm{C}$ ) and clothing required to perform the work (ACGIH, 2018). In this study, metabolic heat $(\mathrm{Kcal} / \mathrm{h})$ was determined and ambient heat (WBGT ${ }^{\circ} \mathrm{C}$ ) was evaluated according to NR 15.

Due to the diverse characteristics of clothing used for phytosanitary application, the present study did not consider adjustments in WBGT depending of the PPE dressing. However, the combination of physical effort coupled with the use of PPE associated with climatic conditions may contribute to increase problems in the workers' health (ROSCANI et al., 2017).
RAMIRIO, L. D. et al.

The worker performing moderate activity under mild climatic conditions using light clothing would take an average of 90 minutes to raise his body temperature by $1.5^{\circ} \mathrm{C}$. If this same worker used waterproof and synthetic clothing, this time would drop to 20 minutes (VILELA et al., 2015). Clothing creates an important barrier in the heat exchanges between the worker's body and the environment, which hinders or prevents the cooling of the body. The efficiency of heat exchanges between the body and the environment depends highly on the material and color that they are manufactured (ROSCANI et al., 2017).

Table 2. Working day for the application of phytosanitary products in coffee crop according to NR 15 in conditions of health and unhealthiness after obtaining the average WBGT.

\begin{tabular}{|c|c|c|c|c|c|}
\hline \multirow[b]{2}{*}{ Schedule } & & \multicolumn{2}{|l|}{ September } & \multicolumn{2}{|l|}{ October } \\
\hline & & $\begin{array}{l}\text { WBGT } \\
\text { AVERAGE } \\
{ }^{\circ} \mathrm{C}\end{array}$ & Work/Rest & $\begin{array}{l}\text { WBGT }_{\text {AVERAGE }} \\
{ }^{\circ} \mathrm{C}\end{array}$ & Work/Rest \\
\hline $\begin{array}{l}\text { 7:00 } \\
\text { 7:59a.m. }\end{array}$ & to & 18.77 & Continuous work & 20.40 & Continuous work \\
\hline $\begin{array}{l}\text { 8:00 } \\
\text { 8:59a.m. }\end{array}$ & to & 20.53 & Continuous work & 22.29 & Continuous work \\
\hline $\begin{array}{l}\text { 9:00 } \\
\text { 9:59a.m. }\end{array}$ & to & 22.07 & Continuous work & 23.18 & Continuous work \\
\hline $\begin{array}{l}\text { 10:00 } \\
\text { 10:59a.m. }\end{array}$ & to & 23.13 & Continuous work & 24.36 & Continuous work \\
\hline $\begin{array}{l}\text { 11:00 } \\
\text { 11:59a.m. }\end{array}$ & to & 23.95 & Continuous work & 25.16 & $\begin{array}{l}45 \text { min work } \\
15 \text { min rest }\end{array}$ \\
\hline $\begin{array}{l}\text { 12:00 } \\
12: 59 \text { p.m. }\end{array}$ & to & 24.45 & Continuous work & 25.96 & $\begin{array}{l}45 \text { min work } \\
15 \text { min rest }\end{array}$ \\
\hline $\begin{array}{l}\text { 1:00 } \\
\text { 1:59p.m. }\end{array}$ & to & 24.31 & Continuous work & 26.08 & $\begin{array}{l}30 \text { min work } \\
30 \text { min rest }^{(1)}\end{array}$ \\
\hline $\begin{array}{l}\text { 2:00 } \\
\text { 2:59p.m. }\end{array}$ & to & 24.20 & Continuous work & 25.74 & $\begin{array}{l}45 \text { min work } \\
15 \text { min rest }\end{array}$ \\
\hline $\begin{array}{l}\text { 3:00 } \\
\text { 3:59p.m. }\end{array}$ & to & 23.17 & Continuous work & 24.22 & Continuous work \\
\hline
\end{tabular}

(1) The rest periods shall be considered work time for all legal purposes.

Regarding the comparison of the data with the NHO 06 the results showed that the limits of occupational exposure for non-acclimatized workers were exceeded at all times, except in the period from 7:00 to 8:59 a.m. and 7:00 to 7:59 a.m. for September and October, respectively (Figure 1). The occupational exposure limits for acclimatized workers had not exceeded at any time in September. However, in October it had exceeded during the period from 11:00 a.m. to 2:59 p.m. (Figure 1).

Acclimatization is a physiological and gradual adaptation that increases the individual capacity to withstand the thermal load (ACGIH, 2018). Due to the physiological adaptability of the organism, a person who is acclimatized to the environmental conditions presents less stress or physiological dysfunctions than a person who is not acclimatized (LAMBERTS, 2016).

Occupational exposure limits for acclimatized or non-acclimatized workers, whenever they exceeded, it will be necessary to adopt preventive measures in order to minimize the probability of exposures causing harm to the worker's health, being one of the options alternating activities with softer metabolic rates, introduction of pauses, in more extreme cases availability of acclimatized or thermally mild work places (GIAMPAOLI et al., 2017). 


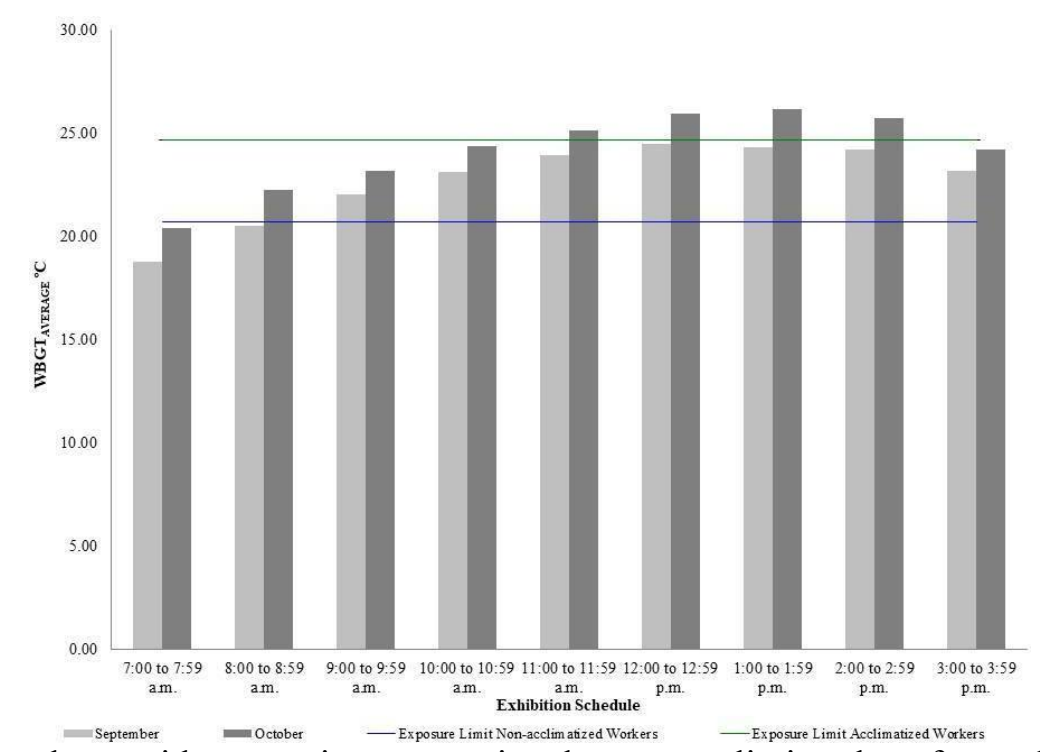

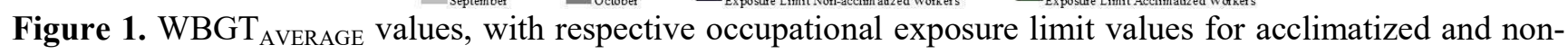
acclimatized workers.

For exposures that occur below the action level, acclimatization of the worker is not necessary. For exposures above the occupational exposure limit for non-acclimatized workers that correspond to the level of action, it will be necessary to adopt preventive measures such as a gradual acclimatization plan, in which the worker will begin his activities in a milder regime starting from the level of action until progressively reach the condition of occupational exposure of the day by day work, seeking to minimize the damages to the worker's health (GIAMPAOLI et al., 2017).

It is not possible to accurately relate occupational injuries with hot environments, but it is observed that in environments with higher temperatures there is an increase in fatigue, loss of concentration and a decrease in resistance (VARGHESE et al., 2018). The risks and impacts of thermal stress due to high temperatures on the workers' health and safety are significantly harmful, requiring management of heat stress impacts on occupancy and worker adaptation strategies (NUNFAM et al., 2018).

Thus, in hot environments there is a need for greater awareness of workers and employers to reduce the risk of injury, health problems and loss of productivity (VARGHESE et al., 2018). Preventive measures should be adopted, including periodic monitoring of workers, encourage of water intake for adequate replacement by sweat loss, training, acclimatization, breaks at work, among others that aim to reduce the workers' health impacts (GIAMPAOLI et al., 2017; AGCIH, 2018). The ACGIH (2018) recommends as a general control measure the performance of pre-admission medical examinations for the identification of workers susceptible to damage caused by heat exposure.

Due to the difficulty of fitting the WBGT $_{\text {AVERAGE }}$ adjustment increase rate through NHO 06, to be used when wearing clothing for phytosanitary applications, it is suggested that new study aimed at determining the increase to be performed, so that we can have a greater precision of the influence in these types of clothes. We emphasize that: hours between 11:00 a.m. and 2:59 p.m. are considered unhealthy for the month of October; being necessary to adjust the work regime in October for not leaving the activity unhealthy; and it is necessary to adopt a gradual acclimatization plan between 9:00 a.m. to 3:59 p.m. and 8:00 a.m. to 3:59 p.m. in September and October, respectively.

\section{ACKNOWLEDGMENTS}

The authors would like to thank the Federal Institute of Education, Science and Technology of the South of Minas (IFSULDEMINAS) - Campus Inconfidentes for the financial aid, availability of the place for accomplishment of data collections and loan of the equipments.

RESUMO: Durante a aplicação de produtos fitossanitários no cafeeiro os trabalhadores podem estar expostos a temperaturas capazes de comprometer sua saúde. Exposição ao calor ocupacional pode levar a desidratação progressiva, câimbras, exaustão e possibilidade de choque térmico. Desta forma, conhecer os 
níveis de calor ocupacional que os trabalhadores estão expostos torna-se importante. O presente estudo teve como objetivo avaliar a exposição ocupacional ao calor de trabalhadores durante a aplicação de produtos fitossanitários com bomba costal manual na cultura do cafeeiro. $\mathrm{O}$ estudo de caso foi desenvolvido na fazendaescola do IFSULDEMINAS - Campus Inconfidentes nos meses de setembro e outubro de 2017. Avaliou-se o calor ocupacional em lavoura cafeeira através do método do IBUTG $_{\text {MÉDIO }}$, utilizando medidor de estresse térmico TGD 400. Os valores do IBUTG encontrados foram comparados aos limites de exposição da NR 15 para fins de classificação de insalubridade e com a NHO 06 para trabalhadores aclimatizados e não aclimatizados. Os resultados demostraram que o IBUTG encontrado está abaixo do limite de tolerância da NR15, para o mês de setembro. No mês de outubro o limite de tolerância foi ultrapassado no período das 11:00 às $14: 59 \mathrm{~h}$, considerando uma atividade pesada contínua e descanso no próprio local de trabalho, sendo a atividade considerada insalubre. Ao considerarmos os critérios da NHO 06 observou-se que os limites de exposição ocupacional foram ultrapassados no mês de outubro, para trabalhadores aclimatizados e não aclimatizados. Em setembro o limite de exposição ocupacional da NHO 06 foi superado somente para trabalhadores não aclimatizados. Portanto os trabalhadores devem ser submetidos à aclimatização durante a atividade de aplicação de fitossanitários no mês de outubro.

PALAVRAS-CHAVES: Calor Ocupacional. IBUTG. Aclimatização. Insalubridade.

\section{REFERENCES}

CONFERENCIA AMERICANA DE HIGIENISTAS INDUSTRIAIS GOVERNAMENTAIS ACGIH Limites de Exposição para Substâncias Químicas, Agentes Físicos e Índices Biológicos - Tradução Associação Brasileira de Higienistas Ocupacionais ABHO, São Paulo, 298p, 2018.

BELO, M. S. S. P.; PIGNATI, W.; DORES, E. F. G. C.; MOREIRA, J. C.; PERES, P. Uso de agrotóxicos na produção de soja do Estado do Mato Grosso: um estudo preliminar de riscos ocupacionais e ambientais.

Revista Brasileira Saúde Ocupacional, São Paulo, v. 37, n. 125, p. 78-88, jan./jun. 2012. http://dx.doi.org/10.1590/S0303-76572012000100011

BRASIL, Ministério do Trabalho e Emprego. Normas Regulamentadoras. NR 15: Atividades e Operações Insalubres. Disponível em: <http://www.mtps.gov.br/>. Acesso em: 06 de maio 2017.

FIEDLER, N. C.; GUIMARÃES, P. P.; ALVES, R. T.; WANDERLEY, F.B. Avaliação ergonômica do ambiente de trabalho em marcenarias no sul do Espírito Santo. Revista Árvore, Viçosa, v. 34, n. 5, p. 907-915, Oct. 2010. http://dx.doi.org/10.1590/S0100-67622010000500016

GIAMPAOLI, E. SAAD, I. F. S.D.; CUNHA, I. A.; SHIBUYA, E. K. Norma de higiene ocupacional 06 - NHO 06: Avaliação da Exposição Ocupacional ao Calor. 2. Ed. São Paulo. FUNDACENTRO, 2017. 48 p.

INSTITUTO BRASILEIRO DE GEOGRAFIA E ESTATÍSTICA - IBGE. Dados amostrais e estimativas populacionais das medianas de altura e peso da população, por sexo, segundo a idade e os grupos de idade Minas Gerais, 2009. Disponível:

http://www.ibge.gov.br/home/estatistica/populacao/condicaodevida/pof/2008_2009_encaa/tabelas_pdf/tab3_17. pdf. Acesso em: 25 de maio de 2017.

KJELLSTROM, T.; LEMKE, B.; VENUGOPAL, V. Occupational Health and Safety Impacts of Climate Conditions. Climate Vulnerability, [s.1.], vol.1, p.145-156, 2013. Elsevier. https://doi.org/10.1016/B978-0-12384703-4.00120-9

LAMBERTS, R. Conforto e stress térmico. Florianópolis: Universidade Federal de Santa Catarina Centro Tecnológico - Departamento de Engenharia Civil, 2016. p.144.

http://www.labeee.ufsc.br/sites/default/files/disciplinas/Apostila\%20Conforto\%20T\%C3\%A9rmico_2016.pdf 
MIRANDA, G. R. B.; SILVA, M. R.; ALVES, A. D.; GONÇALVES, E. J. Quantificação de depósitos e deriva de pulverização diferentes pontas em pulverizador costal no cafeeiro. Coffee Science, Lavras, v. 11, n. 3, p.290-297, jul./set. 2016. http://dx.doi.org/10.25186/cs.v11i3

NUNFAM, V. F.; ADUSEI-ASANTE, K.; ETTEN, E. J. V.; OOSTHUIZEN, J.; FRIMPONG, K. Social impacts of occupational heat stress and adaptation strategies of workers: A narrative synthesis of the literature. Science Of The Total Environment, [s.1.], v. 643, p.1542-1552, dez. 2018. Elsevier BV. https://doi.org/10.1016/j.scitotenv.2018.06.255

R DEVELOPMENT CORE TEAM R Foundation for Statistical Computing, Vienna, Austria, 2016.

ROSCANI, R. C.; BITENCOURT, D. P.; MAIA, P. A.; RUAS, A. C. Risco de exposição à sobrecarga térmica para trabalhadores da cultura de cana-de-açúcar no Estado de São Paulo, Brasil. Cadernos de Saúde Pública, [s.1.], v. 33, n. 3, p.1-15, 20 abr. 2017. http://dx.doi.org/10.1590/0102-311x00211415

SALIBA, T. M. Manual prático de avaliação e controle de calor: PPRA. 7. ed. São Paulo. Editora LTR, 2016. 80p.

SILVA, J. R. M.; TEIXEIRA, R. Sobrecarga térmica em fábrica de móveis. Floresta Ambient. Seropédica, v. 21, n.4, p.494-500. dec. 2014. http://dx.doi.org/10.1590/2179-8087.004012

VARGHESE, B. M.; HANSEN, A.; BI, P.; PISANIELLO, D. Are workers at risk of occupational injuries due to heat exposure? A comprehensive literature review. Safety Science, [s.1.], v. 110, n.1, p.380-392, dez. 2018. https://doi.org/10.1016/j.ssci.2018.04.027

VEIGA, M. M; ALMEIDA, R; DUARTE, F. O desconforto térmico provocado pelos equipamentos de proteção individual (EPI) utilizados na aplicação de agrotóxicos. Laboreal, Porto, v. 12, n. 2, p. 83-94, dez. 2016. http://www.scielo.mec.pt/pdf/lab/v12n2/v12n2a07.pdf. https://doi.org/10.4000/laboreal.2540

VILELA, R. A. G.; LAAT, E. F.; LUZ, V. G.; SILVA, A. J. N.; TAKAHASHI, M. A. C. Pressão por produção e produção de riscos: a "maratona" perigosa do corte manual da cana-de-açúcar. Revista Brasileira de Saúde Ocupacional, São Paulo, v. 131, n. 40, p.30-48, 1 fev. 2015. http://dx.doi.org/10.1590/0303-7657000075413

YANAGI JUNIOR, T.; SCHIASSI, L.; ABREU, L. H. P.; BARBOSA, J. A.; CAMPOS, A. T. Procedimento fuzzy aplicado à avaliação da insalubridade em atividades agrícolas. Engenharia Agrícola. Jaboticabal, vol.32, n.3, p.423-434, Jun. 2012. http://dx.doi.org/10.1590/S0100-69162012000300002 